\title{
The Implementation of the Cultuurstelsel in Java: Cases in Afdeeling Demak and Grobogan, Central Java versus in Afdeeling Pacitan, East Java 1830-1870
}

\author{
Iswahyudi \\ Faculty of Languages and Arts, Universitas Negeri Yogyakarta, Indonesia \\ Email: iswahyudi@uny.ac.id
}

\begin{abstract}
:
The Dutch colonial government in applying the Cultuurstelsel policy in Java in 1830 used traditional Javanese patterns of power to persuade farmers in certain regions to be willing to work in export plantations and surrender a portion of their land to be planted with governorate crops. Based on the description above, it would be interesting to see further about the implementation of the cultivation system in several afdeeling areas or regencies in Java because in Pacitan, East Java, it is said to have an impact on prosperity and welfare for farmers. On the other hand, in other regions, in Afdeeling Demak and Grobogan, Central Java, the opposite happened, namely that the implementation of the forced cultivation system actually had an impact on misery and poverty among the population. Regardless of whether Cultuurstelsel should be valued positively or negatively, most historians agree that the system had been one of the most important parts of Dutch colonialism in the Dutch East Indies from 1830 to 1870. Some at that time even thought that cultuurstelsel was the best colonial model that can be imagined.
\end{abstract}

\section{Keywords:}

Cultuurstelsel; Grobogan; Demak; Pacitan; tobacco; coffee

\section{Introduction}

The history of the Dutch East Indies economy in the 19th century was marked by a period of time called culturstelsel or forced cultivation or also referred to as the cultivation system. This economic system was introduced by Governor General Van den Bosch and began to be implemented in Java in 1830. The reason Van den Bosch implemented the system was because he had previously compared the standard of living of Javanese farmers with those of Dutch farmers which turned out to be much better. This comparison is not caused by the Javanese farmers are lazy, but they must be educated and forced to be more advanced (B.H.M. Vlekke,1932, p.289). The implementation of the cultivation system was mostly carried out in Java in areas directly under the Dutch colonial administration, with the exception of the Vorstenlanden area and privately owned plantations. In areas outside Java there are only a few in certain regions such as coffee growing on the west coast of Sumatra and Minahasa.

In the Culturstelsel policy the Dutch government used traditional Javanese patterns of power to persuade farmers in certain areas to be willing to work in export crop plantations and surrender a portion of their land to be planted with governorate crops. This cooperation is often referred to as admodiasi, in which the village has been changed to support the economic activities of the plantation and economic exploitation (J. Breman, 1986, p. 8). This approach was also a refinement of the VOC's exploitation system because it did not change the traditional economic system which was based on in-kind tax and labor surrender. Through the village heads, the colonial government also promised that the people involved in kulturstelsel would benefit more from planting rice so that they were willing to plant the 
export crops desired by the colonial government. Based on the Regeeringsreglement of 1834 articles 2, 4 and 5, it is stated that by giving up $1 / 5$ of the rice fields owned by the villagers, they will be exempted from paying Land taxes (Landrente) and can get other benefits.

The results of the plants were subsequently processed or processed in private factories which were established through contracts with the colonial government. To establish factories, plantations and supporting infrastructure, the government usually provides working capital to plantation entrepreneurs whose returns are given in the form of colonial government proceeds. Besides that, the colonial government also had the right to determine the types of large-scale plants, including coffee, sugar cane, indigo and small-scale plants which included tea, tobacco, pepper and cinnamon or kaneel (D.H. Burger, 1962, p. 175). Of the various plants that must be planted by the population after going through certain processing, they are sent to Europe. Thus it can be said that culturstelsel is a means of colonial exploitation of the agrarian industry because in its implementation it indirectly forces the Javanese population to plant various tropical export crops at a unilaterally determined planting or plantloon basis. From the results of these plants after being sold to Europe, the profits will be used for the benefit of the mother country treasury (C. Fasseur, 1974, p. 11; J.J.P. de Jong, 1998, p. 270).

\section{Review of Literatures}

Various liberal writers in general always negatively evaluate the implementation of Culturstelsel in Java, including Van Soest, Van Deventer, Gonggrijp, Clive Day, Cornets de Groot and Pierson. Van Soest said that the principles of Stelsel were not implemented or did not even remain the same at all. In practice the portion of the population required to plant crops must be more than $1 / 5$ of the portion as specified, apparently reaching $1 / 3$ or $1 / 2$ part and can even cover the whole village land. Then farmers are only required to work on plantations within one year for 60 days, but in practice they are often forced to work on plantations for 240 days so that the time to work their own land is exhausted (Van Soest, 1869-1871, p. 166).

Farmers should be freed from Landrente payments and even from export crops, but such profits only go to the governor or the contractors. The governor, who should take all the risks in case of crop failure to the extent that it is not caused by negligence and laziness of the farmers, remains the responsibility of the grower farmer. promised to accept the remainder of the release of Van Deventer who wrote in the 1860s overly emphasized the abuses imposed by the forced cultivation system on the Javanese population and sought a restoration of liberal economic principles. Gonggrijp said that the forced cultivation system was nothing but an instrument for the political implementation of the slots of the colonial government which also became a black sheet for the Dutch colonial government. Clive Day places more emphasis on because with uncertainty in the rules, the implementation of forced cultivation allows labor exploitation. Then Corneets de Groot and Pierson in their criticism of the implementation of cultivation system said that the practice of its implementation went wrong because it only emphasized on progress in the private sector (Anne Booth, 1988, p. 99; Suprayitno and Farida Hanum Ritonga, 2918, pp. 127-128). Of the other liberal writers, it is generally argued that the implementation of the Cultivation system diverged greatly from the provisions originally outlined by Van Den Bosch resulting in poverty and misery of the Javanese population.

As a reaction from the liberal writers that led to the emergence of conservative-leaning writers, who generally provide support or defend the interests of the cultel stelsel. One of them was Gerretson, who said that stelsel lice were "de grootste weldaad die Nederlandsch- 
Indie heeft geschonken" which meant that it was the best policy that had been given to the Dutch East Indies (Gerretson, et al., 1928, p. 18).

According to Fasseur, the previous writers who mostly gave negative evaluations of the Selelel culture were generally driven by a liberal spirit. This means that ideological reasons are their main weapon to condemn all the implementation of cultivation system which is indeed coercive. Besides that, on average, their writing is poor with sources (archival sources), so the conclusions drawn are also incorrect. It was further said by Fasseur that as a consequence that could not be denied from the implementation of the Stelsel culture in Java was a heavy burden placed on Javanese people and agricultural land. However, based on archival research both in the form of statistical data and official reports of Dutch employees at that time and other archival information, it can be seen that there are symptoms of prosperity and improvement of the material conditions of Javanese farmers as a result of the implementation of the cultivation system (C. Fasseur, p. 20). An example is Elson's research findings on the planting of governor's sugar cane in Pasuruan, East Java. Elson concluded that as a result of population involvement in these plants they were relatively more prosperous compared to the situation before the implementation of the cultivation system in this area. This prosperity mainly comes from the receipt of wages for planting sugarcane governor whose amount far exceeds the land that must be paid by them (R. E. Elson, 1979).

The description of the cultivation system as a state monopoly which does not allow private entrepreneurs to be involved in it is overly nuanced if not mistaken, by historians Cees Fasseur, Roger Knight and Margaret Leidelmeijer in particular. But the perspective remained in the era between old colonialism from before 1780 and the new from after 1850 to collapse and was marked by the opposition between "government - private". Political events and ideological positions have determined our historical outlook. We see on the other hand, the people and families employed in the Dutch East Indies during the first half of the 19th century, then continuity fell between the decades of 1800-1820 on the one hand and the cultivation system itself on the other (C. Fasseur, 1975; G.R. Knight, 1993; Margaret Leidelmeijer, 1997, pp.18-22; Ulbe Bosma and G. Roger Knight, 2004,pp. 1-26).

Based on the description above, it would be interesting to see further about the implementation of the cultivation system in several regencies areas or regencies in Java because in one particular area it is said to have an impact on prosperity and welfare for farmers. This view, for example, can be seen in the work of Iswahyudi who conducted research in the Pacitan area of East Java (Iswahyudi, 1995). On the contrary, in other areas a conflicting situation occurred, namely that the implementation of the cultivation system actually had an impact on misery and poverty among its inhabitants as can be seen from the work of Agus Supriyono who conducted research in Afdeeling Demak and Grobogan, Central Java (Agus Supriyono, 1987).

\section{Research Methods}

Primary and secondary data collection techniques are carried out through library research which is carried out by visiting various libraries and agencies that store written materials such as the National Archives of the Republic of Indonesia, the National Library of the Republic of Indonesia and other libraries. This step was taken to collect writing sources in the form of archives of the Dutch East Indies government, books, newspapers, magazines and others related to the implementation of the Cultivation System in Java, especially in Demak, Grobogan and Pacitan regencies. After the search for written materials has been completed, the next step is to select and verify the data and compile it into a writing. 


\section{Discussion}

\subsection{Tobacco Planting in Afdeeling Demak and Grobogan, Central Java}

Based on trials of planting various types of export crops carried out by the government in this area in 1833, the types of tobacco and mulberry plants are the most suitable plants to be planted in this area, but this plant was only officially started to be planted in 1844. Until 1847 in this area there were already 8 tobacco plantation entrepreneurs who were given contracts by the government. This type of plant takes a lot of time and energy from grower farmers to maintain it. In the districts of Demak and Grobogan, basically it was determined that for each smell of rice fields worked by 6 families, but in practice for the reasons mentioned above often results in displacement of the population then determined to be done by 8 - 9 families. Tobacco planting until harvesting results takes approximately 7 months (early April to early November) actually exceeds the time needed by farmers to plant rice, which in the Stelsel culture requirements is calculated for 66 days. Besides the maintenance of tobacco plants must be done routinely or continuously. Therefore, it often results in farmers losing or lack of time to work their own paddy fields.

Other work that is quite burdensome for farmers is the construction of infrastructure facilities for the needs of tobacco plantations such as the construction of warehouses, roads, bridges and so on (Edi Sumarno et al., 2019, p. 162). For the construction of warehouses, for example, it would require a lot of wood, bamboo, reeds and etc. which in this case could not be obtained from residents without the help of local native leaders. However, to obtain various building material needs from residents is often done in an undue way because residents do not get compensation or compensation in accordance with market prices. Besides that, local people are also forced to cut and transport wood to make warehouses from quite far away (usually from Rembang) in exchange for inappropriate wages (Van Prehn, 1862, p. 15). This often results in villagers who, although not yet having a turn to grow tobacco, the governor have begun to change residence to avoid mandatory tobacco planting which they say is burdensome.

Since the planting of the governor's tobacco in Afdeeling Demak and Grobogan, many farmers have complained, but the village heads did not dare to report it to the governor. It was only after the inspection was carried out because of the large population movements from Afdeeling that the village heads acknowledged the objection. Another objection to the governor's tobacco planting for growers is the plantloon (planting wages) that are not in accordance with their efforts. For more details in table 1 can be seen about the comparison between landrente to be paid by tobacco growers with the wages earned.

Table 1. Comparison between planting wages and landrente from the governor tobacco farmers in Afdeeling Demak and Grobogan in 1844-1850

\begin{tabular}{|l|l|l|l|l|}
\hline Year & \multicolumn{1}{|c|}{$\begin{array}{c}\text { Plant area } \\
\text { (bau) }\end{array}$} & Family involved & $\begin{array}{c}\text { Wages to plant } \\
\text { each family } \\
\text { (guilders) }\end{array}$ & $\begin{array}{c}\text { Landrente each } \\
\text { family } \\
\text { (guilders) }\end{array}$ \\
\hline 1844 & 250 & 4776 & 5,33 & 7,14 \\
\hline 1845 & 636 & 9429 & 7,00 & 10,05 \\
\hline 1846 & 1094 & 8150 & 13,00 & 10,92 \\
\hline 1847 & 940 & 8095 & 8,80 & 15,92 \\
\hline 1848 & 482 & 6333 & 4,11 & 16,90 \\
\hline 1849 & 270 & 2150 & 9,34 & (unknown) \\
\hline
\end{tabular}

Source: Kultuur Verslag 1844 - 1849, ARADH and ANRI 
From the table above it can be seen that only in 1846 grower farmers received wages that were slightly above the amount of land that they had to pay. For other years (except 1849 because of the unknown size of the land per family) the grower farmer always receives wages for planting that are far below the landholding that must be paid. From the inadequate amount of planting wages, they are often still deceived by the indigenous heads, so that many of them do not receive the wages they are entitled to. As a result, many government tobacco growers left their villages and moved to other places.

According to the provisions prevailing at that time in Afdeeling Demak and Grobogan, the grower farmers should still receive wages for planting even though the governor's tobacco they had planted was unsuccessful or for some reason the land that had been provided had been forced to not be planted at all. This provision can be seen from the condition of the plant as follows:

- Quality number I, wages for planting each bau is 125 guilders.

- Quality number II, wages for planting each bau is 95 guilders.

- Quality number III, wages for planting each bau is 80 guilders.

- Unsuccessful / unsuccessful harvest, the incentive to plant each bau is 50 guilders.

- Not planted, the incentive to plant each bau is 25 guilders.

Based on this provision, it can be seen that the method of paying tobacco planting wages in Afdeeling Demak and Grobogan is very deviant or violates the provisions.

According to Smissaert, the government (governor) was not selective in choosing tobacco contractors in Afdeeling Demak and Grobogan so that the companies did not succeed well ("Nota Smissaert 14 Nopember 1850" in Baud Collection No. 900, ARADH). As an example mentioned contractor Van Lawick van Pabst obtained a contract only because he was a close friend of the Governor-General. He rarely comes to his tobacco plantations so it becomes neglected. Other contracts awarded to other contractors such as Van Amstel and Van der Klein also suffered the same fate as stated above so that the tobacco planting carried out by them failed. This less selective tobacco plantation contract resulted in the planting of tobacco in Afdeeling Demak and Grobogan being less professional so the results were less satisfying. Besides, when the price of Javanese tobacco dropped sharply on the European market in 1846, many contractors suffered losses and had difficulty in repaying the down payment capital provided by the governor and were unable to pay planting wages to farmers involved in it. with its provisions (B.J.O.Schrieke, 1929, p. 109).

Regarding the wage fraud planted by native chiefs is the fault of local European employees who do not try to do prevention. The payment of this planting wage should be overseen by the Assistant Resident official, while the mechanism of the payment itself is through the indigenous heads, who then through the controllers and the village head are given to the grower farmers. This type of fraud has been reported several times, one of which is by Demak Controller Baron Van Rheede van Oudshoorn to the plant Inspector and followed up by an inspection by officials concerned with the Demak Resident Assistant and Grobogan. In addition, there are also reports that Wedono Wirosari has extorted wages from planting and persecuting gubernemen tobacco farmers who are considered not diligent in maintaining and working on their tobacco plants (Rapport van de Inspecteur der Cultures 7 Desember 1849 No. 28).

Due to these burdensome reasons, based on the results of the Plant Inspector's research, it was known that in 1847 there had been a migration of about 15,000 people from Grobogan district. This migration was reported as a reaction of the resentment of the 
population to the governor's tobacco cultivation. Likewise, in Demak Regency, especially in the Manggar District, based on the results of the same investigation it was stated that the planting of the governor's tobacco plantations had resulted in a large influx of population movements from his village. In the same year the population movement rate from this area was known to be around 12,000 inhabitants.

The government tobacco cultivation in Afdeeling Demak and Grobogan which turned out to be unsuccessful also resulted in the government withdrawing 6 contracts out of 8 contracts in 1849, leaving only 2 tobacco planting contracts given to Van der Klein and van Hogendorp which still survived that year (Kultuur Verslag 1849).

\subsection{Coffee Planting in Afdeeling Pacitan, East Java}

When the indigo plant no longer gave high expectations, the Dutch colonial government immediately looked for other products that would provide the maximum profit for their country's financial treasury. The black bean named coffee which had been ignored by the Dutch East Indies government when planting tilapia was being echoed and then glanced back and carried as a mainstay trade product. In their opinion, the production of trade commodities which had been introduced more than a century earlier would be far more profitable than the production of indigo plants. This was proven because a few years after the coffee plantation became the belle of the financial resources of the Dutch East Indies government. This fact was justified by many colonial officials, one of whom was stated by the Director of the Plantation B.J. Elias in 1836 that the highest yields of forced cultivation were obtained from coffee plantations (F. Van Baardewijk, 1986). The increasing amount of financial coffers owned by the government is based on the existence of coffee planting orders accompanied by the concept of plantation management in which there is a traditional command style that demands voluntary work. Between 1833 and 1840 coffee cultivation was expanded again on a large scale.

Coffee is included in the Rubeacease plant species, with tree heights reaching an average of 10 meters. This plant originates from the African continent namely in Kaffa which is an area in the southern Abessinia state. Coffee plants are well planted in areas with an altitude of 1000 meters to 5000 meters above sea level and with temperatures between 16-20 degrees Celsius. This plant is not against wind rain so it must be given a protective plant. The best type of soil for coffee plants is crumb soil that is deep enough, does not hold water and is also not dry. Sandy soil and clay are not suitable for coffee plants if the roots of the coffee plants can still penetrate. The stones function as a water barrier so that they are not blocked and water circulation occurs properly. Coffee plants are mainly grown in gentle, gentle mountain areas. Land in the forest that has not been touched by human hands is very good for this plant (D.G. Stibbe et al. (1919).

In 1696 the Coffee plant was brought for the first time to Java by Van Omsen because he was ordered by Nicholas Wilsen who served as mayor of Amsterdam. The first planting trial in Java was carried out by Governor General Willem Outhorn in the Kedawung area near Batavia. In 1706 this trial was declared a success and there were plans to spread it throughout Java, where the geographical conditions were suitable for planting this plant. The geographical conditions in Pacitan East Java very fulfilled the requirements of the planting of this coffee plant and in 1819 began to be widely planted in this area together with Pepper plants. Because of the prediction that this coffee plant would produce many benefits, in 1820 the colonial government began to order the population to plant this plant in large gardens (Anonim,1871, p. 277). 
Another factor that supports the development of coffee is because it is based on the criteria of the Raad Van Nederlandsch Indie note that in Pacitan there are still many vacant lands or woestegronden. This land is not maintained and does not become the property of individuals or communal land, so it is used as the land of the Governor or the Government. As a place for developing coffee plants, it is hoped that this will not interfere with agricultural land or rice fields belonging to residents planted with food crops. The opening of wastelands is carried out by residents together with the assistance of a group of passengers or residents from other villages and young people who are not married. After this land is opened as a coffee plantation land, the population has ownership rights for 8-10 years. After the time period expires, the land becomes jointly owned or communal land that is not allowed to be traded (Missive van Assistent Resident Patjitan, 24 September 1865, Nummer 1018).

Based on the condition of the land area that is not balanced with the population, all the population of productive age who are exposed to compulsory labor or heerendiensten are involved in coffee cultivation except the village heads and capetengan. Coffee plantations in the Pacitan, Panggul and Lorok districts were initially carried out individually because at that time the land clearing of the farmers plantations, which in general lived far away, obtained a portion of the land. Then for the semanten and Pringkuku districts the Coffee planting was carried out together, after which the land was distributed to the farmers involved in the coffee planting (Missive van Assistent Resident Patjitan, 24 September 1865, Nomor 1018).

Table 2. The state of planting of the Afdeeling Pacitan government coffee in 1855-1864

\begin{tabular}{|ccccc|}
\hline Year & $\begin{array}{c}\text { Number of families } \\
\text { which is involved }\end{array}$ & Productive plants & Young plants & Total \\
\hline 1855 & 12.085 & 3.673 .682 & 2.044 .969 & 5.642 .651 \\
1856 & 11.647 & 3.543 .220 & 2.333 .664 & 5.776 .884 \\
1857 & 12.085 & 3.673 .682 & 2.044 .969 & 5.642 .651 \\
1858 & 12.085 & 3.673 .682 & 2.044 .969 & 5.642 .651 \\
1859 & 12.085 & 3.673 .682 & 2.044 .969 & 5.642 .651 \\
1860 & 12.034 & 4.048 .919 & 2.181 .485 & 6.062 .788 \\
1861 & 12.085 & 3.673 .682 & 2.044 .969 & 5.642 .651 \\
1862 & 10.957 & 4.667 .481 & 1.447 .157 & 6.114 .638 \\
1863 & 12.085 & 3.673 .682 & 2.044 .969 & 5.642 .651 \\
1864 & 12.085 & 3.673 .682 & 2.044 .969 & 5.642 .651 \\
\hline
\end{tabular}

Source: Overzicht 1855-1864 en Rapport Betreffende de Cultures te Patjitan. C 1865 dalam Archieven der Cultures No. 57

Based on the above table, it can be seen that the decline in the number of coffee farmers is a common phenomenon that occurs in almost all regions of Java. In Afdeeling Pacitan the decline mainly occurred during the last four years, but in the previous period the situation was stable or at least remained. 1859 was the peak as seen from the large number of families involved in the governor's coffee planting which were 12,133 families and in 1864 there were 10,957 families. Within five years it was seen that the decline had reached $10 \%$. The declining number of coffee farmers is estimated as a result of population movements. The table above shows that the number of young coffee trees in the last years, ie between 1852-1864 experienced a large decline. Actually the planting of new coffee trees in those years is quite a lot and is not different from the planting of new trees in previous years. It appeared that some of the new coffee plants did not develop well and many died.

The amount of net wages received by governor coffee farmers can also be related to the level of welfare of the population in Afdeeling Pacitan, as shown in the following table. 
Table 3. Money received by farmers growing coffee as payment for the harvest at Afdeeling Pacitan in 1855-1863

\begin{tabular}{|cccc|}
\hline Year & Number of families & $\begin{array}{c}\text { The amount of money } \\
\text { the whole family receives }\end{array}$ & $\begin{array}{c}\text { The amount of money } \\
\text { each family receives }\end{array}$ \\
1855 & 12.065 & f. $206.424,72,-$ & f. $17,11,-$ \\
1856 & 11.674 & f. $80.585,55,-$ & f. $6,90,-$ \\
1857 & 11.731 & f. $113.570,20,-$ & f. $9,68,-$ \\
1858 & 11.731 & f. $113.570,20,-$ & f. $9,68,-$ \\
1859 & 11.731 & f. $113.570,20,-$ & f. $9,68,-$ \\
1860 & 11.589 & f. $148.048,80,-$ & f. $12,77,-$ \\
1861 & 11.589 & f. $148.048,80,-$ & f. $12,77,-$ \\
1862 & 11.589 & f. $148.048,80,-$ & f. $12,77,-$ \\
1863 & 11.095 & f. $228.079,66,-$ & f. $20,37,-$ \\
\hline
\end{tabular}

Source: Archieven der Cultures No. 57

Based on the tabekl above, the net wages received by governor coffee growers every year are not always the same. When compared with the prices of basic commodities in Afdeeling Pacitan, the amount of money received is sufficient to meet the daily needs of farmers. By comparison of the lowest wage received by farmers in 1856 of 6.90 guilders it means that it is still profitable for farmers because with that much money they can buy as much as 2 pikul rice. One picul of rice is equivalent to 31.76 kilograms and the average price of rice in Pacitan in 1856 was 3.25 guilders for each pikul, while the net wage received by the governor of coffee farmers in 1856 was 6.90 guilders. The calculation in detail is that the wages received by each farming family will be able to meet the needs of rice for 347 days.

To see the more intensive implementation of coffee planting in Afdeling Pacitan, it can be seen in more detail in the reports from the Pacitan District and the Panggul District, which in this case can be a representation of all districts included in the Afdeling Pacitan region.

Table 4. Comparison of the number of farming families with farming families involved in growing coffee in Pacitan District in 1855-1864

\begin{tabular}{|cccc|}
\hline Year & Number of farming families & $\begin{array}{c}\text { Number of farming families } \\
\text { involved in coffee cultivation }\end{array}$ & $\begin{array}{r}\text { Percentage } \\
(\%)\end{array}$ \\
\hline 1855 & 3.070 & 2.885 & 94 \\
1856 & 2.896 & 2.896 & 100 \\
1857 & 3.816 & 2.747 & 72 \\
1858 & 2.900 & 2.900 & 100 \\
1859 & 2.900 & 2.900 & 100 \\
1860 & 3.820 & 2.926 & 77 \\
1861 & 3.820 & 2.926 & 77 \\
1862 & 3.205 & 2.929 & 91 \\
1863 & 3.097 & 2.029 & 95 \\
1864 & 3.112 & 2.810 & 94 \\
\hline
\end{tabular}

Source: Archieven der Cultures No. 57 
Table 5. Comparison of the number of farming families with farming families involved in growing coffee in Panggul District in 1855-1864

\begin{tabular}{|cccc|}
\hline Year & Number of farming families & $\begin{array}{c}\text { Number of farming families } \\
\text { involved in coffee cultivation }\end{array}$ & $\begin{array}{c}\text { Percentage } \\
(\%)\end{array}$ \\
\hline 1855 & 2.924 & 2.742 & 94 \\
1856 & 3.816 & 2.747 & 72 \\
1857 & 3.816 & 2.747 & 72 \\
1858 & 2.900 & 2.900 & 100 \\
1859 & 2.900 & 2.900 & 100 \\
1860 & 3.820 & 2.926 & 77 \\
1861 & 3.820 & 2.926 & 77 \\
1862 & 3.823 & 2.809 & 73 \\
1863 & 3.747 & 2.593 & 69 \\
1864 & 3.786 & 2.593 & 93 \\
\hline
\end{tabular}

Source: Archieven der Cultures No. 57

Table 6. Number of productive coffee trees and money received by each family of coffee growers for harvests that were deposited to the Government in Pacitan District in 1855-1864

\begin{tabular}{|c|c|c|c|}
\hline Year & \multicolumn{2}{|c|}{$\begin{array}{l}\text { The number of productive } \\
\text { coffee trees }\end{array}$} & $\begin{array}{c}\text { Payment money received } \\
\text { by each family }\end{array}$ \\
\hline 1855 & 803.629 & trees & f. 8,20 ,- \\
\hline 1856 & 822.89 & 》, & f. $2,23,-$ \\
\hline 1857 & 1.116 .25 & , & f. $2,78,-$ \\
\hline 1858 & 822. 89 & " & f. $2,23,-$ \\
\hline 1859 & 822.89 & , & f. $2,23,-$ \\
\hline 1860 & 726.634 & ” & f. $4,91,-$ \\
\hline 1861 & 969.692 & ״ & f. $6,10,-$ \\
\hline 1862 & 726.634 & , & f. $4,91,-$ \\
\hline 1863 & 726.634 & " & f. $4,91,-$ \\
\hline 1864 & 853.468 & , & f. $1,93,-$ \\
\hline
\end{tabular}

Source: Archieven der Cultures No. 57

Table 7. Number of productive coffee trees and money received by each family of coffee growers for harvests that were deposited to the Government in the Panggul District in 18551864

\begin{tabular}{|c|c|c|c|}
\hline Year & \multicolumn{2}{|c|}{$\begin{array}{l}\text { The number of productive } \\
\text { coffee trees }\end{array}$} & $\begin{array}{c}\text { Payment money received } \\
\text { by each family }\end{array}$ \\
\hline 1855 & 692.046 & trees & f. $26,62,-$ \\
\hline 1856 & 669.091 & , & f. $15,08,-$ \\
\hline 1857 & 736.456 & , & f. $12,18,-$ \\
\hline 1858 & 806.741 & , & f. $26,38,-$ \\
\hline 1859 & 829.200 & , & f. $16,49,-$ \\
\hline 1860 & 917.100 & (") & f. $49,80,-$ \\
\hline 1861 & 942.700 & , & f. $36,88,-$ \\
\hline 1862 & 980.900 & , & f. $15,19,-$ \\
\hline 1863 & 943.220 & , & f. $42,23,-$ \\
\hline 1864 & 994.467 & , & f. $6,44,-$ \\
\hline
\end{tabular}

Source: Archieven der Cultures No. 57 
Based on the table above with the exception in 1864, the money received by each family of the average coffee grower in the Panggul District can be said to be very satisfying. With the calculation as in the table above, the money received by each average family of farmers between the period of 1855 to 1864 was 25 guilders. This amount of money can be used to buy 7 piculs of rice or to buy 1-3 buffalos. In addition, the large number of productive coffee trees does not always affect the amount of money received by farmers for their crops which are handed over to the Government.

\section{Conclusion}

The implementation of the the Cultivation system in Afdeeling Demak and Grobogan, especially for the cultivation of tobacco, can be said to be unfavorable to the local people involved and vice versa, even adding to their burden. As a result, many residents who left their villages to avoid this obligatory planting. however, this cannot be interpreted to mean that the implementation of the Cultivation system in these areas was the main and direct cause of the famine that occurred in this region in 1849-1850. This is understandable if it is reviewed that the total area of land used for planting government tobacco is too small (1094 bau) when compared to the total area of agricultural land (113033 odors). Likewise, the number of families involved in growing tobacco is the number of 8150 families of the total family of 77323 families, or in this case only around $7.2 \%$. Thus, the way of implementing the Cultivation system that deviates from the provisions is a factor that is more detrimental to the local population than the amount of labor and land burden placed on the population.

Coffee plantations in Pacitan have a positive impact on the population. The expansion of plantations caused villages in Pacitan to become open to outside influences. They became aware that planting commercial crops was felt to be more profitable than planting food crops. In addition to the government coffee plant, the residents also plant fence coffee which is managed and harvested for their own needs. The opening of Pacitan and Panggul ports is the second international shipping center after Cilacap which is a place for trading activities of various export crops and products that are needed by the population. This domestic trade has led to a greater awareness of the population on the importance of the second cultivation, home industry activities and livestock business.

The unpredictable condition of government plantations continues to deteriorate and signs of change are increasingly apparent. A much different situation is experienced by businesses that are funded by the private sector. Entering 1860, the comparison of production results for all export commodities between government estates and private estates began to be balanced. In fact, the colonial government still carried out compulsory work practices for farmers in managing their plantations. Obviously, this further strengthened the pressure made by the liberals in the Dutch parliament to immediately end the Cultivation System. Moreover, since the 1850s, the coalition of the support force of Cultuurstelsel has weakened and the colonial government of the Dutch East Indies has become the only political force that has continued to support the implementation of this system. In its development, the liberals in parliament continued to get fresh air related to the end of the system which they considered to be obsolete and old-fashioned throughout the 1860s. Until then in 1870, the Cultivation System was officially terminated by the government and replaced by a more modern and liberalistic system, through the Agrarian Law. Since a few years earlier, compulsory planting in a number of areas had indeed been stopped, but still in 1870 it must be considered as the most important and major trail for the end of the period of terrible exploitation in the history of the Archipelago. 


\section{References}

Archieven der Cultures No. 57 : Overzicht 1855-1864 en Rapport Betreffende de Cultures te Patjitan. C 1865.

Baud Collection No. 900, ARADH

Missive van Assistent Resident Patjitan, 24 September 1865, Nummer 1018

Anonim, "De Koffie Cultuur op Java", Tijdschrift van Nederlandsch Indie, I, 1871

Baardewijk, F. Van, "Rural response to intensifying colonial exploitation; peasant reactions to the introduction and intensification of the forced cultivation of coffe in central and east Java, 1830-1880", Paper for the 5th Dutch-Indonesian Historical Conference, Lage Vuursche, 1986

Bosma, Ulbe (2005), "Het Cultuurstelsel en zijn Buitenlandse Ondernemers: Java tussen oud en nieuw kolonialisme, Tijdschrift voor sociale en economische geschiedenis 2 nr. 2 , pp. 3-28.

Bosma, Ulbe and G. Roger Knight (2014), 'Global factory and local field: Convergence and divergence in the international cane-sugar industry, 1850-1940', in: International Review of Social History 49, 1.

Breman, J. (1986), Penguasaan Tanah dan Tenaga Kerja Jawa di Masa Kolonial, Translated by LP3ES. Jakarta: LP3ES

Breman, J. (1982), "Village Java and the Early Colonial State", Journal of Peasant Studies, vol.9, No.4

Burger, D.H (1962), Sedjarah Ekonomis Sosiologis Indonesia, Djilid 1, Translated by Prajudi Atmosudirdjo. Djakarta, Prandjaparamita

De Jong, J.J.P., (1998), De waaier van het fortuin. De Nederlanders in Azië en de Indonesische archipel 1595-1950.Den Haag

Fasseur, C., 1975, Kultuurstelsel en Koloniale Baten: de Nederlandse Exploitatie van Java 1840-1860, Universitaire Pers Leiden, Leiden. Frederick

Fasseur, C., ed. (1980), Geld en geweten. Een bundel opstellen over anderhalve eeuw Nederlands bestuur in de Indonesischearchipel in de negentiende eeuw, Den Haag

Furnivall, J.S., 1948, Netherlands Colonial Policy and Practice: A Comparative Study of Burma and the Netherlands-Indie, Cambridge University Press, Cambridge.

Gerretson, et al. (1928), De sociaal economische invloed van Nederlandsch-Indie op Nederland. Wageningen

Gorkom, K.W. Van, (1866), Gedwongen arbeid en kultures, Tijdschrift voor Nijverheid en Landbouw in Nederlandsch-Indie, 12, No. Seri 7

Iswahyudi (1995), "Dari Mancanegara Timur menjadi Kabupaten Pacitan: Suatu Kajian Proses Perubahan Sosial Pada Abad XIX", Unpublished thesis Postgraduate Faculty, University of Gadjah Mada Yogyakarta

Klaveren J.J. Van (1983) The Culture-System (Cultuurstelsel). In: The Dutch Colonial System in the East Indies. Springer, Dordrecht. https://doi.org/10.1007/978-94-017-6848-114

Knight, G.R. (1993), Colonial production in provincial Java. The sugar industry in Pekalongan-Tegal 1800-1942,Amsterdam

Leidelmeijer, Margaret (1997), Van suikermolen tot grootbedrijf. Technische vernieuwing in de Java-suikerindustrie in de negentiende eeuw, Amsterdam.

Fernando, M. R. (1982), Peasants and plantation economy; The Social Impact of the European Plantation Economy in Cirebon Residency from the Cultivation Sustem to the First Decade of the Twentieth Century, Monash University, Melbourne

Schrieke, B.J.O. (1929), The Effect of Western Influence on Native Civilizations in the Malay Archipelago. Batavia 
Stibbe, D.G., et al. (1919), Encyclopaedie van Nederlandsch-Indie. Derde Deel, s'Gravenhage Martinus Nijhoff, Leiden, NV. v/h E.J. Brill

Sumarno, Edi et al.(2019), "The Cities in East Sumatera after the Development of Plantation Industry 1863-1942”. Budapest International Research and Critics Institute-Journal (BIRCI-Journal) Volume 2, No 2, May, Page: 150-164. DOI : https://doi.org/10.33258/birci.v2i2.246

Suprayitno and Farida Hanum Ritonga (2018), "The Sunggal War 1872-1895: In Search of East Sumatera Local Wisdom”. Budapest International Research and Critics InstituteJournal (BIRCI-Journal) Volume I, No 3, October, Page: 126-136. DOI: https://doi.org /10.33258/birci.v1i3.36

Agus Supriyono (1987), "Krisis Subsistensi di Karesidenan Semarang: Kasus kelaparan di Afdeeling Demak dan Grobogan Tahun 1849/50, Unpublished thesis Postgraduate Faculty, University of Indonesia Jakarta

Van Niel, Robert (1972), "Measurement of Change under the Cultivation System in Java 18371851", Indonesia, No. 14 (Oktober), Cornell Modern Indonesia Project

Van Soest, Geschiedenis van het Kultuurstelsel III. Rotterdam, Nijgh, 1869-1871

Vlekke, B.H.M. (1932), Nusantara. Kuala Lumpur: Dewan Bahasa Malaysia 